\title{
PEMANFAATAN FILM DOKUMENTER THE COVE SEBAGAI MEDIA KAMPANYE PENYELAMATAN LUMBA
}

\author{
Desak Putu Yogi Antari Tirta Yasa ${ }^{1^{*}}$, I Nyoman Payuyasa ${ }^{2 *}$
}

\author{
Program Studi Film dan Televisi \\ Fakultas Seni Rupa dan Desain \\ Institut Seni Indonesia Denpasar \\ Jl. Nusa Indah, Sumerta, Kota Denpasar, Kode Pos 80235 \\ Bali. Indonesia \\ Email: buahpinus@gmail.com
}

\begin{abstract}
Abstrak
Film dokumenter merupakan sebuah film yang menyajikan fakta kepada penontonnya dan dapat menjadi sebuah media kampanye mengenai suatu permasalahan. Film The Cove menampilkan kekejaman industri penangkaran dan pertunjukkan lumba-lumba dari sudut pandang seorang aktivis bernama Richard O' Barry. The Cove kemudian tidak hanya menjadi sebuah film dokumenter, tapi juga menjadi media kampanye untuk bergerak melawan kekejaman terhadap industri tersebut. Metode yang digunakan dalam penelitian ini adalah metode kualitatif, dimana metode analisis data yang digunakan adalah metode kualitatif-interpretatif. Teori yang digunakan dalam penelitian ini adalah teori mengenai film dokumenter, genre dan gaya film dokumenter, unsur-unsur film dan teori komunikasi terkait dengan kampanye. Film The Cove menggunakan gaya participatory atau yang dikenal dengan istilah observasi partisipan. Gaya ini dapat membawa penonton merasa berada pada situasi yang sama dengan pembuat film sehingga dapat menimbulkan pengaruh yang kuat dalam diri penonton. Unsur-unsur dalam film The Cove terdiri dari unsur visual dan unsur verbal, dimana kedua unsur tersebut membangun satu kesatuan dalam film. Pemanfaatan The Cove sebagai media kampanye penyelamatan lumba-lumba mampu memberi dampak yang kuat di masyarakat berkat pemilihan gaya dokumenter serta pemanfaatan unsur visual dan verbal film yang tepat, sehingga pesan penyelamatan lumba-lumba dapat sampai kepada masyarakat.
\end{abstract}

Kata Kunci: film dokumenter, media kampanye, cove.

\begin{abstract}
Documentary film is a film that presents the facts to the audience and can be a media campaign about an issue. The Cove film shows the cruelty of the captivity industry and dolphin shows from the point of view of an activist named Richard $O$ 'Barry. The Cove then not only became a documentary film, but also became a media campaign to move against cruelty to the industry. The method used in this study is a qualitative method, where the data analysis method used is a qualitative-interpretative method. The theory used in this study is the theory of documentary film, documentary film genre and style, elements of film and communication theory related to the campaign. The Cove film uses a participatory style, known as participant observation. This style can bring the audience to feel in the same situation as the filmmaker so that it can cause a strong influence in the audience. The elements in the film The Cove consist of visual elements and verbal elements, where the two elements build a unity in the film. Utilization of The Cove as a media campaign to save dolphins can have a strong impact on the community thanks to the selection of documentary styles and the use of appropriate visual and verbal elements of the film, so that the message of saving dolphins can reach the public.
\end{abstract}

Keywords: documentary film, campaign media, cove.

\section{PENDAHULUAN}

Film dokumenter The Cove yang diproduksi pada tahun 2009 melahirkan gerakan masif di seluruh dunia mengenai penyelamatan lumba-lumba, termasuk memberi pengaruh pada gerakan penolakan sirkus lumba-lumba di Indonesia. Indonesia adalah satu dari sedikit negara yang masih melegalkan sirkus lumbalumba keliling. Permasalahan sirkus lumba-lumba dinilai memiliki urgensi tinggi untuk bisa diselesaikan dengan cepat. Atraksi lumba-lumba dinilai lebih sebagai tindakan eksploitasi ketimbang tindakan konservasi dan edukasi. Film dokumenter The Cove dijadikan salah satu media kampanye penyelamatan lumba-lumba karena mampu memberikan informasi mengenai permasalahan tersebut dalam media audiovisual. 


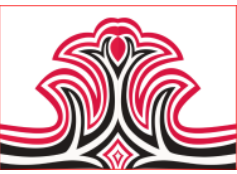

Pemanfaatan film dokumenter The Cove sebagai media kampanye penyelamatan lumba-lumba menarik untuk dikaji, dimana sebuah film dokumenter dapat menjadi media kampanye efektif yang membawa perubahan besar mengenai permasalahan yang belum populer di masyarakat. Dalam penelitian ini, dikaji permasalahan mengenai bagaimana pemanfaatan film dokumenter The Cove sebagai media kampanye penyelamatan lumba-lumba dan bagaimana unsurunsur film dalam film dokumenter The Cove dapat menyampaikan pesan kampanye penyelamatan lumbalumba.

Tujuan penelitian ini adalah mengkaji pemanfaatan film dokumenter The Cove sebagai media kampanye penyelamatan lumba-lumba dan mengkaji unsur-unsur film dalam film dokumenter The Cove dalam menyampaikan pesan mengenai penyelamatan lumbalumba.

Penelitian mengenai pemanfaatan film dokumenter The Cove sebagai media kampanye penyelamatan lumba-lumba penting untuk dilakukan mengingat film ini mampu mendorong gerakan masif penyelamatan lumba-lumba secara global. Hasil dari kajian ini nantinya diharapkan dapat menjadi acuan bagaimana memanfaatkan sebuah film sebagai media kampanye dan bagaimana memanfaatkan unsur-unsur film untuk mencapai hasil yang diinginkan.

\section{KAJIAN TEORI}

\section{Film Dokumenter}

Film dokumenter bukanlah reproduksi dari realita melainkan representasi dari dunia yang kita tinggali. Film dokumenter menstimulasi keingintahuan dari penontonnya, dengan cara menyampaikan informasi logis, retorika dan persuasif maupun peristiwa puitik yang menjanjikan informasi, pengetahuan, wawasan dan kesadaran (Nichols, 2001:10). Dalam buku Documentary Storytelling oleh Shila Currant Bernard, disebutkan bahwa dengan memperlihatkan bukti dan informasi, penonton diberikan kesempatan untuk dapat merasakan cerita secara pribadi serta mengantisipasi adegan dan mengikuti jalan cerita secara aktif

Film dokumenter dapat dibagi menjadi enam jenis menurut gaya filmnya, diantaranya: poetic, expository, participatory, observational, reflexsive, dan performative. Film The Cove menggunakan gaya participatory atau yang dikenal dengan istilah observasi partisipan. Gaya ini dapat membawa penonton merasa berada pada situasi yang sama dengan pembuat film. Film dokumenter bergaya
Gorga Jurnal Seni Rupa

Volume 08 Nomor 02 Juli-Desember 2019 p-ISSN: 2301-5942 | e-ISSN: 2580-2380

observasi partisipan dapat menimbulkan pengaruh yang kuat dalam diri penonton, sehigga film ini mampu memberikan dampak yang kuat di masyarakat. Ciri khas dari gaya film dokumenter ini adalah keterlibatan langsung si pembuat film dengan objeknya. Hal ini menuntun penonton untuk dapat merasakan dan menjadi saksi dari dialog antara pembuat film dan objek film tersebut.

Film dokumenter juga terbagi atas beberapa genre. Menurut Gerson dalam buku "Dokumenter Dari Ide Hingga Produksi", klasifikasi dalam genre film dokumenter terbentuk dari berbagai film yang memiliki kesamaan tema, latar, dan bentuk. Film dokumenter The Cove bergenre investigasi, dimana film dokumenter tersebut bercerita tentang penyelidikan atas suatu objek yang melakukan perekaman fakta, peninjauan, percobaam dan sebagainya dengan tujuan untuk memperoleh jawaban atas pertanyaan-pertanyaan tersebut.

\section{The Cove Movie}

Film dokumenter The Cove secara garis besar bercerita tentang kekejaman terhadap lumba-lumba. Di Taiji, Jepang, nelayan lokal menyembunyikan fakta mengerikan mengenai penangkapan dan pembunuhan lumba-lumba secara massal. Penangkapan lumbalumba di Taiji terkait dengan pasokan lumba-lumba untuk sirkus lumba-lumba di beberapa wilayah di dunia. Aktivis Ric O'Barry, bersama sutradara Louis Psihoyos dan The Ocean Preservation Society mengungkap praktik kejam ini.

Penonton dikenalkan pada sosok aktivis penyelamatan lumba-lumba Richard O'Barry yang lebih dikenal dengan Ric O'Barry. The Cove yang dirilis resmi pada 31 Juli 2009 di Amerika Serikat telah memenangkan banyak penghargaan diantaranya Academy Award for Best Documentary Feature, pemenang dalam Best Documentary Environmental Media Awards (2009), Pemenang Best Documentary New York Film Criticts Online (2009), Pemenang The Audience Award International Documentary Festival Amsterdam, dan puluhan penghargaan lainnya.

\section{METODE PENELITIAN}

Penelitian pemanfaatan film dokumenter The Cove sebagai media kampanye penyelamatan lumba-lumba menggunakan menggunakan metode penelitian kualitatif. Subjek dalam penelitian ini adalah film dokumenter The Cove. Objek penelitian dalam penelitian ini adalah kajian mengenai pemanfaatan film dokumenter The Cove sebagai media kampanye penyelamatan lumba-lumba. Penelitian pemanfaatan 
film dokumenter The Cove sebagai media kampanye penyelamatan lumba-lumba akan di lakukan di wilayah Bali, yakni daerah Badung dan Denpasar dimana kegiatan kampanye penyelataman lumbalumba terus dilakukan oleh penggiat satwa termasuk dengan media film dokumenter The Cove.

Peneliti menggunakan teknik snowballing sampling / teknik sampling bola salju. Beberapa informan awal dalam penelitian ini adalah penggiat penyelamatan lumba-lumba dari yayasan dan komunitas lokal di Bali dan penggiat penyelamatan lumba-lumba dari Jaan Indonesia.

Teknik analisis yang digunakan dalam penelitian ini metode yang bersifat kualitatif-interpretatif, yaitu sebuah metode yang memfokuskan dirinya pada tanda dan teks sebagai objek kajiannya, serta bagaimana bagaimana peneliti menafsirkan dan memahami kode dibalik tanda tersebut. Secara sederhana, film dapat dipandang sebagai sebuah teks karena dalam film terdapat tanda-tanda yang mengandung makna. Hasil penelitian akan disajikan secara deskriptif analitif melalui uraian dan didukung dengan tabel dan gambar.

\section{HASIL DAN PEMBAHASAN \\ 1.Hasil}

Lumba-lumba adalah mamalia laut yang termasuk dalam ordo Cetacea. Kata Cetacea berasal dari bahasa Latin yaitu Cetus yang berarti hewan yang besar dan bahasa Yunani Ketos yang berarti monster laut. Satwa yang termasuk dalam ordo Cetacea adalah satwa menyusui (mamalia) yang sepanjang hidupnya ada di perairan dan telah melakukan berbagai adaptasi untuk kehidupannya di lingkungan tersebut. Lumba-lumba atau dolphin dikelompokkan dalam famili Delphinidae dengan belasan ragam genus.

Eksploitasi terhadap lumba-lumba terjadi di berbagai belahan dunia dalam berbagai bentuk. Di Indonesia bentuk eksploitasi lumba-lumba paling banyak terjadi pada sirkus lumba-lumba yang dibalut dengan kemasan peragaan untuk kepentingan edukasi. Indonesia juga menjadi satu-satunya negara yang masih melegalkan sirkus lumba-lumba keliling.

Jaan Indonesia merupakan salah satu organisasi di Indonesia yang aktif melakukan gerakan perlawanan terhadap eksploitasi lumba-lumba. Jaan Indonesia bekerjasama dengan Doplhin Project, organisasi penyelamatan lumba-lumba yang dibentuk oleh Ric O' Barry, tokoh utama di balik film dokumenter The
Cove. Jaan Indonesia aktif melaksanakan kampanye penyelamatan lumba-lumba sejak tahun 2008.

Film merupakan salah satu media yang banyak digunakan oleh Jaan Indonesia dalam kegiatan kampanye penyelamatan lumba-lumba. The Cove menjadi film yang dipilih dalam kegiatan kampanye di Indonesia. Jaan Indonesia sudah menggunakan The Cove sebagai media kampanyenya sejak tahun 2009.

Screening The Cove oleh Jaan Indonesia dilaksanakan di berbagai wilayah Indonesia termasuk Bali. Berikut beberapa pemutaran film The Cove yang diadakan oleh Jaan Indonesia :

1. 19 Maret 2011, DEUS Café, Canggu, Bali

2. 21 Maret 2011, Universitas Gajah Mada, Yogyakarta

3. 22 Maret 2011, Jakarta

4. 9 Februari 2013, Tugu Hotel, Bali

5. 30 April 2017, Sanur, Bali

6. 31 Agustus 2019, Vision Villa Resort, Bali

7. 5 September 2019, Institut Seni Indonesia Denpasar, Bali.

Sejak memulai kampanye penyelamatan lumba dengan kegiatan pemutaran film The Cove dalam program Edukasi untuk mendukung penyelamatan lumba-lumba di Indonesia, Jaan Indonesia mengakui adanya perubahan signifikan yang terjadi di lapangan. Kampanye penyelamatan lumba-lumba tidak hanya dilakukan oleh Jaan Indonesia semata, berbagai gerakan dari komunitas dan organisasi lokal di berbagai wilayah Indonesia bermunculan, diantaranya aksi penolakan sirkus lumba-lumba keliling di Balikpapan, Samarinda, Medan, Solo, dan Yogyakarta. Di Bali pernah ada penolakan terhadap peragaan lumba-lumba di Wake Park yang berlokasi di Keramas, Bali.

\section{Pembahasan}

John Grierson menemukan istilah dokumenter dalam suatu pembahasan mengenai film Moana tahun 1925 yang merupakan karya dari Robert Flaherty. Grierson mengacu pada kemampuan suatu media untuk menghasilkan dokumen visual tentang suatu kejadian tertentu. Grierson menyebutkan bahwa sinema bukanlah seni atau hiburan, melainkan suatu bentuk publikasi dan dapat dipublikasikan dengan 100 cara yang berbeda untuk 100 orang yang berbeda. Karenanya, dokumenter termasuk di dalamnya sebagai suatu metode publikasi sinematik yang disebut perlakuan kreatif atas keaktualitasan (creative 
treatment of actuality) oleh Grierson. Dokumenter adalah usaha untuk menampilkan kembali situasi nyata dan orang-orang yang terlibat di dalamnya, seperti yang dituliskan dalam buku Directing The Documentary oleh Michael Rabiger.

Dokumenter sering dianggap sebagai rekaman dari aktualitas, potongan rekaman sewaktu kejadian sebenarnya berlangsung, saat orang yang terlibat di dalamnya berbicara, kehidupan nyata seperti apa adanya, spontan, dan tanpa media perantara. Unsurunsur tersebut merupakan ramuan utama dalam membuat film dokumenter. Namun unsur-unsur tersebut jarang menjadi keseluruhan film dokumenter, karena semua bahan tersebut harus diatur, diolah kembali, ditata struktur penyajiannya sehingga pesan yang ingin disampaikan dapat diterima dengan baik oleh penonton.

Unsur-unsur daam film dokumenter terbagi atas unsur visual dan unsur verbal. Dalam buku An Introduction to Film Studies, edisi ketiga, oleh Jill Nelmes, disebutkan bahwa unsur-unsur visual dan verbal yang biasa digunakan dalam sebuah dokumenter adalah :

\section{1). Usur Visual}

terdiri dari:

\section{(1). Observasionalisme Reaktif}

Pembuatan film dokumenter dengan bahan yang sebisa mungkin diambil langsung dari subjek yang difilmkan. Hal ini berhubungan dengan ketepatan pengamatan oleh pengarah kamera atau sutradara.

\section{(2). Observasionalisme Proaktif}

Pembuatan film dokumenter dengan memilih materi film secara khusus sehubungan dengan pengamatan sebelumnya oleh pengarah kamera atau sutradara.

\section{(3). Mode Ilustratif}

Pendekatan terhadap dokumenter yang berusaha menggambarkan secara langsung tentang apa yang dikatakan oleh narator (yang direkam suaranya sebagai voice over).

\section{(4). Mode Asosiatif}

Pendekatan dalam film dokumenter yang berusaha menggunakan potongan-potongan gambar dengan berbagai cara. Dengan demikian diharapkan arti metafora dan simbolis yang ada pada informasi harafiah dalam film itu dapat terwakili.

\section{2). Unsur Verbal} terdiri dari:

\section{(1). Overhead Exchange}

Rekaman pembicaraan antara dua sumber atau lebih yang terkesan direkam secara tidak sengaja dan secara langsung.

\section{(2). Kesaksian}

Rekaman pengamatan, pendapat, atau informasi yang diungkapkan secara jujur oleh saksi mata, pakar, dan sumber lain yang berhubungan dengan subjek dokumenter. Hal ini merupakan tujuan utama dari wawancara.

\section{(3). Eksposisi}

Penggunaan voice over atau orang yang langsung berhadapan dengan kamera, secara khusus mengarahkan penonton yang menerima informasi dngan argumen-argumennya.

Pemanfaatan unsur verbal dan visual dalam film dokumenter The Cove selanjutnya akan dijelaskan dalam contoh kajian adegan yang terjadi dalam film The Cove berikut :

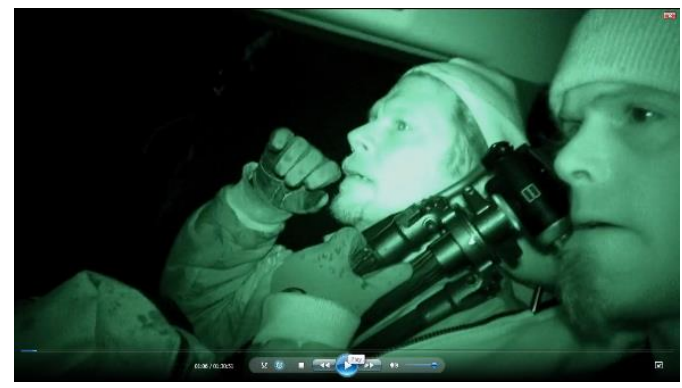

Gambar 1. Screen Shots The Cov e 01:06 (Sumber: Desak Putu Yogi Antari Tirta Yasa, 2019)

Unsur Visual: Observasionalisme Reaktif.

Gambar di atas merupakan gambar dari Charles Hambleton dan Brooke Aitken yang berada di jok belakang mobil yang dikendarai oleh Ric. Mereka mengemukakan beberapa kalimat mengenai rencana pengambilan gambar secara sembunyi-sembunyi di Teluk Taiji. Wajah mereka terlihat tegang. Gambar diambil dengan mode "night view" yang menambah kesan misterius dan menegangkan.

Unsur verbal: Overhead Exchange.

Percakapan yang terjadi antara dua sumber, yakni Charles Hambleton dan Brooke Aitken yang direkam secara langsung.

\section{KESIMPULA DAN SARAN}

\section{Kesimpulan}

Pemanfaatan The Cove sebagai media kampanye penyelamatan lumba-lumba mampu memberi dampak yang kuat di masyarakat berkat pemilihan gaya dokumenter serta pemanfaatan unsur visual dan verbal 
film yang tepat. Gaya dokumenter yang digunakan adalah gaya dokumeter participatory atau observasi partisipan. Dalam gaya documenter ini, penonton seolah dilibatkan secara langsung dalam film, sehingga pesan yang ingin disampaikan pada penonton dapat tersampaikan dengan baik. The Cove menggunakan gaya ini untuk menyampaikan pesan tentang penyelamatan lumba-lumba, dimana pesan tersebut mampu mengubah stigma yang selama ini ada di masyarakat mengenai pertunjukkan lumba-lumba atau lumba-lumba yang hidup dalam penangkaran. Fakta mengenai kekejaman yang terjadi dalam industri pertunjukkan lumba-lumba disajikan lewat unsur verbal dan visual dalam film, sehingga mampu memberikan sudut pandang baru bagi penonton. Hasilnya, film The Cove berhasil menjadi sebuah media kampanye penyelamatan lumba-lumba, bahkan menjadi acuan untuk gerakan penolakan terhadap sirkus dan penangkaran lumba-lumba di berbagai belahan dunia, termasuk di Indonesia.

\section{Saran}

Pemanfaatan The Cove sebagai media kampanye penyelamatan lumba-lumba merupakan salah satu bukti bahwa film adalah sebuah media yang efektif untuk menyampaikan informasi kepada masyarakat. Pemilihan gaya film serta pemanfaatan unsur-unsur film memegang peranan penting dalam menentukan keberhasilan sebuah film sebagai media kampanye. Di Indonesia, sirkus lumba-lumba serta bentuk-bentuk eksploitasi terhadap lumba-lumba masih banyak terjadi, terutama di wilayah pariwisata seperti Bali. Gerakan kampanye penyelamatan lumba-lumba dapat dilakukan dengan lebih gencar mengadakan acara pemutaran film The Cove yang disertai dengan edukasi mengenai prinsip-prinsip kesejateraan hewan. Para penggiat dan pembuat film dapat bekerjasama untuk menghasilkan film sejenis The Cove dalam melakukan kegiatan kampanye penyelamatan hewan.

\section{DAFTAR RUJUKAN}

Bernard, Shila Curran. (2007). Documentary Storytelling. USA: Elsevier.

Nichols, Bill. (2001). Introduction to Documentary. USA: Indiana University Pers.

Rabiger, Michael. (2004). Directing The Documentary. United States of America: Focal Press. 